\title{
KESERUPAAN DENGAN YESUS DALAM PENDERITAAN, KESENGSARAAN DAN KEMATIAN-NYA
}

\author{
Lewi Nataniel Bora \\ Sekolah Tinggi Teologi Injili Arastamar (SETIA) Jakarta \\ lewi@sttsetia.ac.id
}

\begin{abstract}
Following Jesus has risks that must be faced. Everyone who will enter into fellowship with Him will be challenged. That challenge to "take up the cross" was presented by Jesus when He was in the world. Everyone who follows Him, will experience suffering. The suffering faced is not the result of a grievous error, but because of the differences between the self-gratifying normal of the previous situation to the self-denying that Jesus calls us too. A person is required to imitate Jesus in facing the various suffering from self-denying that results from his fellowship with Jesus. A person who can endure suffering will continue to be in fellowship with Jesus. Fortitude in dealing with such situations will lead to similarity with Jesus. Similarity is an important part of fellowship with Jesus.
\end{abstract}

Keywords: Similarity, suffering, self-emptying, self-denying, take up the cross.

Abstrak: $\quad$ Mengikut Yesus memiliki risiko yang harus dihadapi. Setiap orang yang akan masuk dalam persekutuan dengan Dia akan mendapatkan tantangan. Tantangan untuk "memikul salib" telah disampaikan oleh Yesus ketika Dia berada di dalam dunia.Seseorang yang mengikuti Dia, akan mengalami penderitaan. Penderitaan yang dihadapi bukanlah akibat dari kesalahan yang menyedihkan, tetapi karena perbedaan antara hudip pada kepuasan diri dengan penyangkalan diri saat Yesus memanggi kita.Seseorang dituntut untuk mencontohi Yesus dalam menghadapi berbagai penderitaan yang ada akibat dari penyangkalan diri yang dihasilkan dari persekutuannya dengan Yesus. Seseorang yang dapat bertahan dalam penderitaan akan terus berada dalam persekutuan dengan Yesus.Ketabahan dalam menghadapi situasi tersebut akan membawa pada keserupaan dengan Yesus. Keserupaan merupakan bagian penting dalam persekutuan dengan Yesus.

Kata kunci: Keserupaan, penderitaan, mengosongkan diri, menyangkal diri, memikul salib.

\section{PENDAHULUAN}

Penderitaan menjadi situasi dimana manusia mengalami rasa tidak nyaman dalam hidupnya. Penderitaan bisa dari dalam diri ataupun dari pihak lain. Kesalahan pribadi bisa mendatangkan penderitaan pada diri sendiri. Penderitaan ini hanya bisa diselesaikan oleh pribadi yang mengalaminya. Banyak hal yang bisa jadi penyebab munculnya penderitaan itu. Penderitaan yang dialami manusia 
berawal dari dosa yang mereka lalukan. Dosa yang terus mengikuti manusia ke mana pun ia bergerak, menyebabkan penderitaan yang tak berkesudahan. Bagi ..., penderitaan terjadi karena adanya pertentangan antara manusia dengan Allah dan sesamanya. ${ }^{1}$ Putusnya hubungan Allah dengan manusia mengakibatkan pertentangan yang sangat besar. Kehidupan manusia menjadi rusak sehingga hubungannya dengan semua hal di sekitarnya pun ikut menjadi rusak.

Perjanjian Lama memberikan catatan mengenai penderitaan. Contoh yang paling jelas adalah Ayub. Penderitaan yang dialami Ayub bukanlah kesalahan pribadi melainkan adanya penyabab dari luar, dan penyebab tersebut adalah iblis. Iblis yang mendatangi Tuhan untuk memohon agar Ayub diuji, apakah dia benarbenar saleh atau hanya karena Tuhan terus memberikan yang baik sehingga tetap setia. Tuhan menyetujui proses itu namun tidak mengizinkan iblis mengganggu nyawanya. Semua yang ada pada Ayub diambil oleh iblis dengan berbagai cara. Tidak ada yang tersisa padanya. Dalam keadaan itu Ayub tetap saja setia kepada Tuhan. Melihat keadaan itu, iblis lalu memberikan penyakit, namun penyakit tersebut tetap saja tidak menyebabkan Ayub menyangkal Tuhan. Dia menjalani penderitaan itu hingga selesai. Dia tetap setia kepada Tuhan, sekalipun dia juga tetap merasa kesal karena penderitaan yang menimpahnya sangat berat.

Yeremia juga mengalami penderitaan selama melakukan pelayanan di Yehuda. Selama 40 tahun dia melayani, dia mengalami banyak penolakan baik dari pihak istana maupun imam dan rakyat biasa.Yeremia tetap setia melakukan pelayanan kenabiannya sekalipun tidak membawa hasil yaitu pertobatan bangsa Israel Selatan. Mereka tetap berkeras dengan kehidupan yang menjauh dari

\footnotetext{
1 Sonny Zaluchu, "Penderitaan Kristus Sebagai Wujud Solidaritas Allah Kepada Manusia," Dunamis: Jurnal Teologi dan Pendidikan Kristiani, 2017, 61-74.
} 
Tuhan.Yeremia mendapatkan kekuatan dari Tuhan dan beberapa orang yang masih tetap berpaut kepada Tuhan.

Keseluruhan Alkitab memberikan keterangan yang sangat jelas bahwa kehidupan manusia dipenuhi penderitaan. Mulai dari Kejadian 3. Ketika manusia lebih memilih untuk melakukan kehendaknya sendiri yaitu memakan buah yang dilarang oleh Tuhan, maka penderitaan itu mulai muncul.Mereka sadar kalau mereka telanjang, diberikan hukuman, dan diusir dari Taman Eden. Penderitaan itu tidak selesai pada pengusiran, melainkan terus berlanjut. Semua generasi mengalami banyak penderitaan karena dosa yang disebabkan oleh pelanggaran manusia pertama. Paulus menuliskan dalam Roma 8: 22 bahwa semua makhluk merasakan penderitaan karena kesalahan manusia. Semua makhluk sama-sama mengeluh dan merasakan sakit bersalin. Kejatuhan manusia ke dalam dosa menyebabkan semua sistem dalam ciptaan menjadi kacau balau.Manusia yang semula dapat menikmati buah tanpa harus bersusah payah mencari, harus bekerja keras untuk mendapatkan makanan.Kesusahan itu harus dilalui oleh manusia jika mau bertahan hidup dalam dunia yang telah kacau balau.Kebutuhan manusia tidak tersedia seperti di Taman Eden melainkan harus menyediakan sendiri supaya dapat memenuhi kebutuhannya.

\section{METODE}

Penulis menggunakan metode studi pustaka. ${ }^{2}$ Banyak literatur yang membahas mengenai penderitaan dihadapi oleh Yesus dan pengikut-Nya. Penulis

${ }^{2}$ Studi kepustakaan adalah kegiatan untuk menghimpun informasi yang relevan dengan topik atau masalah yang menjadi objek penelitian. Informasi tersebut dapat diperoleh dari buku-buku, karya ilmiah, tesis, disertasi, ensiklopedia, internet, dan lain-lain. (Other Apps, "Pengertian Studi Kepustakaan," diakses 11 Oktober 2020, https://www.transiskom.com/2016/03/pengertian-studi-kepustakaan.html.) 
memakai beberapa buku untuk menunjang proses penulisan artikel ini.Selain buku, penulis juga memakai sumber dari internet dan jurnal online.Penulis menganalisa secara biblika mengenai keserupaan orang percaya dengan penderitaan Kristus. Di bagian awal penulis membahas mengenai penderitaan Kristus saat berada di dunia. Pada bagian kedua penulis membahas mengenai penderitaan Kristus yang akan didapatkan juga oleh orang percaya.

\section{HASIL}

Berdasarkan penelurusuran dari beberapa ayat dalam Alkitab serta bukubuku yang menjadi referensi, penulis menemukan bahwa seseorang yang telah dipilih oleh Tuhan untuk masuk dalam persekutuan-Nya, akan terus menghadapi banyak penderitaan. Penderitaan itu bukan disebabkan oleh kesalahan pribadi, melainkan karena perbedaan situasi yang dialami. Nilai dunia dan nilai baru yang dimasukinya berbeda sehingga menimbulkan penderitaan karena perbedaan. Penolakan dunia terhadap Yesus, akan dirasakan juga oleh orang-orang yang menjadi pengikut-Nya. Orang yang mampu bertahan dalam penderitaan merupakan karunia dari Tuhan.

\section{PEMBAHASAN}

Dalam pembahasan ini akan memberikan penjelasan tentang Yesus Kristus yang telah mengalami penderitaan dan bagaimana teladan yang diberikan oleh Yesus Kristus dalam menghadapi penderitaan. Selanjutnya penulis akan memberikan sebuah paduan prinsip teologis dan praktis dalam menghadapi penderitaan. 


\section{Berinkarnasi Menjadi Manusia}

Injil Yohanes memberikan keterangan bahwa Yesus telah ada sebelum segala sesuatu diciptakan. Dia turut serta dalam penciptaan alam semesta.Dia sudah ada sejak semula.Awal dari segala sesuatu dia ketahui. Yesus meninggalkan surga dan masuk ke dalam dunia. Masuk ke dalam dunia berarti berada di dalam tempat yang dibatasi oleh waktu. Penghuni dunia berakhir dengan kematian. Bumi dan penghuninya bersifat fana, sehingga tidak dapat bertahan selama-lamanya. Keadaan ini berlawanan dengan keadaan Yesus. Yesus adalah Allah yang kekal, namun mengosongkan diri-Nya untuk masuk ke dalam dunia. Mengosongkan diri bukan berarti melepaskan seluruh atribut keallahan dan menjadi manusia seutuhnya, melainkan hanya melepaskan hak-hak yang melekat pada diri-Nya dan mengambil rupa seorang hamba. ${ }^{3}$ Dia masuk ke dalam dunia dengan mengikuti aturan dunia sehingga harus menanggalkan hak-hak-Nya yang selama ini melekat pada diri-Nya. Kekuasaan-Nya yang tidak terbatas harus ditekan supaya dapat merasakan apa yang dialami oleh manusia sebagai makhluk yang terbatas.

Yesus datang ke dunia untuk melaksanakan kehendak Bapa-Nya. Kehendak ini harus terlaksana sesuai dengan rencana yang telah ditetapkan oleh Bapa.Yesus harus menjadi bagian dari manusia sehingga dapat menyelamatkan manusia. Kedatangan-Nya akan berbeda jika lengkap dengan semua atribut-Nya sebagai Allah. Manusia bisa langsung takjud dan percaya dengan semua hal yang dilakukan-Nya. Tindakan ini tidak sesuai dengan rencana Allah.Respons dari manusia yang berlebihan bukanlah indikator untuk menyelamatkan mereka.Allah telah memikili keputusan tersendiri yang berbeda dengan keadaan dan kehendak manusia.

${ }^{3}$ R. P. Martin, "Kenosis," dalam Ensiklopedi Alkitab Masa Kini, 1 (Jakarta: YKBK, 2011), 545. 
William Hendriksen memberikan beberapa poin yang menunjukkan pengosongan diri Yesus saat datang ke dunia. Pertama, Dia melepaskan hubungannya yang menguntungkan dengan hukum ilahi. ${ }^{4}$ Kedua, Dia menyerahkan kekayaan-Nya.Ketiga, Dia menyerahkan kemuliaan surgawiNya.Keempat, Dia melepaskan pelaksanaan otoritas-Nya yang independen. ${ }^{5}$ Berdasarkan poin yang diberikan oleh Hendriksen, terlihat bahwa Yesus benarbenar melepaskan hak-Nya ketika datang ke dunia. Dia datang mengikuti kondisi manusia yang lemah.

\section{Ditolak Oleh Manusia}

Penolakan terhadap Yesus sudah dimulai sejak kelahiran-Nya. Orangtuanya tidak mendapatkan penginapan untuk tinggal saat melakukan sensus di Betlehem.Yesus terpaksa dilahirkan di sebuah kandang (Luk. 2: 7). Penginapan bisa saja penuh karena banyaknya orang yang datang ke Betlehem untuk mendaftarkan diri sebagai orang yang berasal dari Betlehem.

Orang Majus melihat bintang dan datang untuk menyembah orang yang ditunjukkan bintang itu. Bintang itu mengarahkan mereka ke Betlehem di mana Yesus telah dilahirkan. Mereka tidak dapat menemukannya, sehingga mereka harus bertanya kepada Raja Herodes. Gelar yang diberikan oleh orang Majus yaitu Raja orang Yahudi menyebabkan Herodes berusaha membunuh-Nya. Gelar inilah yang menyebabkan Yesus harus disingkarkan dari daerah di mana dia dilahirkan. Herodes membunuh semua bayi yang diperkirakan seumuran dengan Yesus.Yesus yang masih bayi harus berpindah-pindah tempat karena ditolak oleh pemerintah yang berkuasa pada saat itu.

4 William Hendriksen, Galatia, Ephesians, Philippians, Colossians, and Philemon (Grand Rapids: Baker Academic, 2007), 107.

5 Hendriksen. 108. 
Informasi mengenai hubungan Yesus dengan keluarga-Nya tidak terlalu jelas. Hanya ada beberapa peristiwa di mana saudara-saudara Yesus dimunculkan (Mat. 12: 46-50; Mrk. 3: 31-35; Luk. 19-21). Ketiga perikop ini menunjukkan bahwa Yesus lebih mengasihi saudaraa-saudara yang mau melakukan firman Tuhan.Orang-orang yang selalu berada bersama-sama dengan Dia, itulah saudarasaudara-Nya.Yohanes 7: 3 dituliskan bahwa saudara-saudara-Nya menyuruh Dia untuk memperlihatkan ke dunia keajaiban dan mukjizat yang bisa dilakukanNya.Keinginan mereka bertentangan dengan tujuan Yesus datang ke dunia.Sepertinya saudara-Nya juga tidak mengenal Yesus dengan baik.Mereka belum percaya kepada Yesus sekalipun telah hidup lama bersama dengan mereka.

Rasul Yohanes menuliskan beberapa perkataan Yesus yang menunjukkan alasan mengapa Dia dibenci oleh dunia.Perkataan pertama terdapat dalam Yohanes 8: 23, dalam ayat ini dituliskan bahwa Yesus bukan berasal dari dunia. Itulah sebabnya mengapa manusia tidak mengenal-Nya.Asal Yesus berbeda dengan asal manusia.Perbedaan ini menyebabkan manusia tidak dapat mengenal pribadi dan Firman yang dikatakan-Nya.

\section{Mengorbankan Dirinya Untuk Menebus Manusia}

Keempat injil menuliskan pemberitahuan mengenai kesenggaraan yang akan dialami oleh Yesus. Pemberitahuan pertama dilakukan setelah Petrus membuat sebuah pengakuan yang menyatakan diri-Nya sebagai Mesias anak Allah. Yesus menyampaikan bahwa Dia akan menderita. Penderitaan-Nya bukan datang dari bangsa lain melainkan atas keinginan bangsa Israel. Penderitaan itu bisa terjadi karena adanya dukungan kuat dari para pemimpin agama. Mereka akan membuat persepakatan untuk membunuh Dia (Mat. 16: 21; Mrk. 8: 31; Luk. 
9: 9: 22).Ketiga Injil menunjukkan penekanan di bagian akhir yaitu akan adanya kebangkitan pada hari ketiga. Kematian yang dialami oleh Yesus hanya untuk sementara saja.Penekanan ini belum dimengerti oleh Petrus dan murid yang lain, sehingga mereka harus menjadi pengajaran yang lebih dalam lagi.

Pemberitahuan kedua mengenai kesengsaraan-Nya dilakukan oleh Yesus setelah Dia dimuliakan di atas gunung. Yesus kembali menyampaikan bahwa Dia akan mengalami sengsara. Dia akan diserahkan ke dalam tangan manusia. Mereka akan membunuh Dia (Mat. 17: 22-23; Mrk. 9: 31; Luk. 9: 44). Pada pemberitahuan kedua, Injil Matius dan Markus sama-sama menuliskan mengenai kebangkitan pada hari ketiga, namun Injil Lukas sudah tidak menuliskannya lagi. Respons murid sudah berubah sekalipun mereka tetap tidak mengerti maksud dari perkataan yang disampaikan kepada mereka.

Pemberitahuan ketiga disampaikan oleh Yesus ketika hendak pergi ke Yerusalem. Dia menyampaikan bahwa kematian-Nya sudah mendekat. Dia akan diserahkan oleh bangsa Israel kepada bangsa-bangsa yang tidak mengenal Allah. Yesus kembali menegaskan bahwa kematian-Nya sudah pasti terjadi, namun Dia akan bangkit pada hari ketiga (Mat. 20: 17-19; Mrk. 10: 33-34;Luk. 18: 31-32). Yesus selalu memberitahukan kematian-Nya hanya kepada kedua belas murid yang selalu bersama-sama dengan Dia. Sekalipun sudah diberitahukan sampai tiga kali, namun mereka belum mengerti juga maksud dari kematian yang akan dialami oleh Yesus. Penderitaan dan kematian Yesus Kristus adalah bagi pendamaian manusia dari dosa. ${ }^{6}$

\footnotetext{
${ }^{6}$ Made Nopen Supriadi dan Iman Kristina Halawa, "Makna Penderitaan Kristus Dalam 1Petrus 2: 1821," Manna Rafflesia 5, no. 1 (Oktober 2018): 69-91, https://doi.org/10.38091/man_raf.v5i1.99.
} 
Rasul Yohanes menyampaikan dengan caranya sendiri. Penyampaian Yesus mengenai kematiannya dituliskan setelah peristiwa pengelu-eluan Yesus di Yerusalem. Yesus menyampaikan bahwa satu biji gandum harus mati dulu supaya bisa menghasilkan buah. Perumpamaan ini dihubungkan dengan diri-Nya yang harus mati untuk banyak orang. Dia memilih untuk menerima keharusan itu sebab itulah tujuan-Nya datang ke dunia. Cara penyampaian Yesus di Injil Yohanes memiliki keunikan tersendiri. Dia tidak secara langsung menyatakan bahwa akan mati melainkan menggunakan kata-kata yang menyiratkan bahwa Dia akan mati. Pada penyampaian ini disampaikan kepada orang banyak. Dia tidak membawa khusus murid-murid-Nya ke tempat lain.

Taman Getsemani merupakan tempat di mana Yesus harus mengambil keputusan. Dia akan tunduk kepada kehendak Bapanya atau melepaskan tanggung jawab itu. Dia bergumul dengan keadaan itu. Chrisope menghubungkan pergumulan Yesus di Taman Getsemani dengan pencobaan di padang gurun. Kedua keadaan ini menuntut keputusan dari Yesus, apakah Dia akan memakai otonomi pribadinya atau tunduk kepada kehendak Bapa. ${ }^{7}$

Pergumulannya di Getsemani memperlihatkan betapa beratnya beban yang akan ditanggung oleh Yesus. Dia mengajak ketiga murid-Nya untuk menemaniNya selama menjalani pergumulan di taman tersebut. Dia membutuhkan dukungan dari orang-orang yang ada di sekitar-Nya.Sekalipun para murid tetap tidak mengerti penderitaan yang sedang dialami oleh Yesus.Mereka tidak kuat menahan kantuk sekalipun Yesus sudah menunjukkan gejala penderitaan yang berat.

7 Terry A. Chrisope, Mengakui Yesus Sebagai Tuhan (Surabaya: Momentum, 2018), 129. 
Kondisi diri Yesus digambar dengan kata-kata yang kuat untuk menunjukkan gejolak batin. Ketiga Injil menggunakan kata-kata yang benar-benar menggambarkan perasaan Yesus yang sangat berat dan bergejolak. Dalam Injil Matius dituliskan, "Maka mulailah Ia merasa sedih dan gentar, lalu kata-Nya kepada mereka: hati-Ku sangat sedih, seperti mau mati rasanya" (Mat. 26: 37-38). Markus menuliskan, "Ia sangat takut dan gentar" (Mrk. 14: 33). Injil Lukas memberikan penggambaran yang lebih spesifik lagi.Keadaan Yesus sepertinya lebih mencekam.Yesus berdoa sampai peluhnya menjadi seperti titik-titik darah yang bertetesan ke tanah (Luk. 22: 44). Penggambaran yang dipakai ketiga Injil menunjukkan bahwa Yesus merasakan tekanan yang begitu berat.

Dia bergumul dengan pekerjaan yang harus diselesaikan-Nya. Dia ingan lepas dari kewajiban itu. Itulah keinganan pribadi yang dinyatakannya, namun dalam pergumula itu, Dia sadar akan kehendak Bapa. Cawan yang ada di hadapan-Nya harus segera diminum oleh-Nya.Pergumulan untuk meminumnya sangat berat. Menurut Chrisope: "Alasan bagi keenganan ini mungkin adalah karena Yesus mengetahui cawan yang akan Ia minum itu berisi murka Allah."8 Everet Harrison memberikan penjelasan terhadap pergumulan berat yang dihadapi Yesus di Taman Getsemani. Menurut Harrison:

Apa yang menggetarkan Sang Juruselaamt adalah ketakutan akan keterpisahan dari Allah karena menjadi penanggung dosa manusia. Ia sudah lama merenungkan apa artinya hal itu bagi-Nya, tetapi sekarang waktunya telah tiba dan hal itu membuat-Nya kewalahan. Ia mulai menatap piala itudan memahami isinya yang sangat mengerikan. Ia dengan senang hati berteman dengan pendosa dan bersukacita di dalamnya, tetapi sekarang Ia akan diperhitungkan sebagai seorang pendosa, yang berdiri di tempat orang berdosa, dan menanggung kutuk orang berdosa. Gelapnya

8 Chrisope, 129. 
malam di Getsemani menjadi bayang-bayang dari kegelapan yang akan menyelimuti Golgota. ${ }^{9}$

Setelah melalui pergumulan di Getsemani, Yesus sepenuhnya siap untuk menghadapi kematian-Nya. Sepanjang pemaparan mengenai persidangan, hingga kematian-Nya di salib, tidak pernah lagi Yesus menunjukkan keluhan yang mirip dengan peristiwa di Getsemani. Penyelesaian rencana Bapa sepenuhnya telah siap untuk diselesaikan oleh Yesus. Sekalipun orang-orang yang ada di sekitar-Nya menuntut agar Dia mempertontonkan kuasa-Nya, namun Dia tetap memilih diam. Pilatus mengajukan tawaran agar Yesus dapat bebas, namun semuanya tidak dipedulikan sebab kehendak Bapa-Nya telah siap untuk diselesaikan.

Penderitaan Yesus mencapai puncaknya saat disalibkan. Dia menerima semua penderitaan dan dipertontonkan kepada manusia.Yesus tidak mati di tempat yang tersembunyi dan hanya disaksikan oleh keluarga dan orang terdekat. Dia mati di atas salib dan disaksikan banyak orang.Dia menerima penderitaan itu. Keluhan terakhir yang Yesus berikan adalah pernyataan bahwa Dia haus (Yoh. 19: 28). Keluhan itu disampaikannya sebelum Dia menyatakan bahwa segala yang menjadi bagian-Nya telah selesai.

\section{Keserupaan Dengan Yesus Dalam Penderitaan, Kesengsaraan Dan Kematian-Nya}

Yesus memberitahukan kepada murid-murid-Nya bahwa Dia akan menderita. Pendertiaan itu sudah menjadi bagian dari kedatangan-Nya.Dia akan mati di tangan orang-orang yang setiap hari bergumul dengan kitab suci. Kematian-Nya akan terjadi di Yerusalem. Pernyataan itu menyebabkan Petrus bereaksi. Reaksi Petrus sangat ditentang oleh Yesus. Yesus tidak setuju dengan 
pernyataan Petrus sebab hal itu bertentangan dengan rencana yang telah disusun oleh Allah. Menurut Leon Morris:

Yesus lalu berkata bahwa Petrus menjadi batu sandungan baginya. Jika diterima, usulan Petrus ini akan menyesatkan Yesus dan menjauhkan Dia dari kematian yang menjadi inti Injil. Masalahnya adalah Petrus tidak berpikir secara benar.Pikiran mereupakan istilah umum yang secara lebih harfiah berarti "perihal"; pikiran Petrus tidak diarahkan pada hal yang dari Allah. Melainkan mengandung nuansa adversatif yang kuat; bukannya memikirkan apa yang dipikirkan Allah, pikiran Petrus justru sejalan dengan pikiran manusia. Sangat wajar jika kita memikirkan kemuliaan, kehormatan, kenyamanan, dan keamanan.Kita sulit memahami banyak hal dari perspektif Allah yang benar dan mengasihi kebenaran (Mzm. 11: 7).Pandangan Petrus tentang kemesiasan Yesus telah diakui dan karena itu, baginya tidak masuk akal jika kemesiasan ini meliputi penolakan, kesengsaraan, dan kematian. ${ }^{10}$

Petrus membuat pengakuan yang telah diakui oleh Yesus. Dia telah menyatakan bahwa Yesus adalah Mesias, Anak Allah. Pengakuan itu memiliki pengaruh yang kuat untuk mendorong Petrus membuat pernyataan tersebut. Pengharapannya akan Mesias sangat kuat. Dia memahami Mesias sebagai tokoh yang kuat dan memiliki kemampuan seperti Daud.Respons ini sangat alami dari manusia.Pernyataan Morris menunjukkan bahwa Petrus belum sepenuhnya memahami Mesias. Dia masih memahaminya sebagai raja yang akan memimpin Israel secara dunia. Tokoh yang akan membawa kebebasan dan kedamaian bagi bangsanya. Bagi Darrell L. Bock, Petrus memiliki pemahaman yang sangat kuat mengenai Mesias. Dalam pemahaman Petrus, Mesias adalah sosok yang mulia dan berkuasa, bukan orang yang ditolak oleh bangsa Israel. ${ }^{11}$ Pemahaman ini yang disampaikan oleh Bock menunjukkan bahwa Petrus belum sepenuhnya memahami Mesias dari perspektif yang disampaikan oleh Yesus.Dia masih memegang teguh anggapan yang dipegang oleh bangsanya.Mesias tidak mungkin

10 Leon Morris, Injil Matius (Surabaya: Momentum, 2016), 439439.

11 Darrell L. Bock, Jesus According to Scripture: Restoring the Portrait from the Gospels (Grand Rapids: Baker Academic, 2002), 232. 
ditolak oleh bangsa Israel sebab sosok itulah yang sangat dinanti-nantikan sehingga pernyataan Yesus yang berhubungan dengan penderitaan-Nya tidak sesuai dengan pengharapan Mesianik bangsa Israel.

Tanggapan terhadap respons Petrus kemudian memunculkan penjelasan mengenai syarat untuk mengikut Yesus. Penjelasan ini ditujukan kepada semua murid-Nya. Sekalipun hanya Petrus yang menunjukkan reaksi radikal dari pernyataan Yesus, namun Yesus tetap menjelaskan ketentuan itu kepada murid yang lain. Menurut Bock, respons yang diberikan oleh Petrus menjadi alasan yang kuat untuk memberikan pengajaran kepada murid-murid Yesus sebab mereka belum mengerti rencana Allah. ${ }^{12}$ Khusus untuk kalimat pembuka, Morris memberikan penjelasan,

Lalu ... di sini berarti "berikutnya"; setelah dengan keras menolak usulan Petrus yang sangat bersifat duniawi, Yesus berbicara pada seluruh murid. Yesus telah memberitahu kepada pengikut-Nya bahwa Ia harus menderita dan sekarang di dalam kalimat yang serupa dengan 10: 38-39, ia berkata para pengikut-Nya juga harus siap menderita. Ucapan Yesus ini bersifat hipotesis tetapi positif. Setiap berarti merujuk kepada siapapun yang akan menjadi murid-Nya. Mau teramat penting; menjadi murid harus dengan kemauan orang yang bersangkutan, tidak bisa menjadi pengikut Yesus karena ikut-ikutan.Di dalam mengikut Yesus harus ada keputusan sepenuh hati. Mengikut Aku bisa berarti sekadar berjalan di belakang Yesus kemana pun Ia pergi tetapi di dalam konteks ini, hampir pasti berarti "menjadi murid," "menjadi pengikut yang berkomitmen."

Yesus memberikan penjelasan mengenai ketentuan mengikuti Dia. Pengikutnya akan diperhadapkan dengan hal-hal yang mungkin saja baru bagi mereka. Perubahan akan terjadi pada orang yang mengikuti-Nya. Perubahan inilah yang menuntut komitmen dari orang yang akan menjadi pengikut-Nya. Tanpa komitmen tersebut, maka pengikut yang baru akankembali kepada kehidupan awal.

12 Bock, 232.

13 Morris, Injil Matius, 439. 


\section{Menyangkal Diri}

Menyangkal diri merupakan bagian dari pembahasan mengenai pemuridan yang dilakukan oleh Yesus (Matius 16: 24, Mrk. 8: 34, Luk. 9: 23). Seseorang yang ingin mengikuti-Nya harus mengikuti ketentuan-ketentuan pemuridan yang ada dalam sistem-Nya. Jika sistem itu tidak dipatuhi maka seseorang tidak mampu untuk masuk dalam proses pemuridan yang dilakukan oleh Yesus. Mengikuti Dia berarti siap untuk melakukan tuntutan yang telah tersedia. Tuntutan itu harus dipenuhi.

Yesus datang ke dalam dunia dalam keadaan sebagai Allah dan sekaligus manusia. Dia mampu untuk membunuh siapa yang melawan atapun menolak untuk percaya kepada-Nya.Kekuasaan itu tidak dipakai Yesus sebab dia telah melepaskan haknya untuk memakai kuasa itu. Dia datang untuk melayanai manusia sehingga harus mengosongkan diri-Nya supaya dapat hidup dengan manusia.

Pengikut Yesus diberikan syarat pertama yaitu menyangkal diri. Bagi Terry A. Chrisope menyangkal diri berarti menolak secara total. ${ }^{14}$ Seorang murid yang akan mengikut Yesus akan menolak seluruh kepentingan dirinya dan sepenuhnya datang kepada Yesus. Dia menganggap rugi kepentingan diri sendiri.Menurut Chrisope menyangkal diri berarti tidak memandang keuntungan atau kenyamanan diri sendiri. ${ }^{15}$ Mengikuti Yesus berarti melepaskan seluruh kepentingan pribadi. William Hendriksen menyatakan,

To deny oneself means to renounce the old self, the self as it is apart from regenerating grace. A person who denies himself gives up all reliance on whatever he is by nature, and depends for salvation on God alone. He no longer seeks to promote his own predominantly selfish interest but has

${ }^{14}$ Chrisope, Mengakui Yesus Sebagai Tuhan, 129.

15 Chrisope, 130. 
become wrapped up in the cause of promoting the glory of God in his own and in every life and also in every sphere of endeavor. ${ }^{16}$

Ketundukkannya di taman Getsemani merupakan salah satu penyangkalan diri Yesus. Dia menundukkan semua kuasa yang ada pada diri-Nya dan sepenuhnya melakukan kehendak Bapa. Dia mematikan semua kehendak-Nya dan sepenuhnya melakukan apa yang Bapa kehendaki. Dia menyerahkan diri-Nya sepenuhnya kepada kehendak Bapa. Chrisope beranggapan bahwa Yesus bisa sepenuhnya mematikan kehendak diri-Nya setelah Dia melalui pergumulan yang berat. ${ }^{17}$ Proses pemuridan akan melalui proses ini. Pelepasan kehendak diri dan sepenuhnya masuk ke dalam kehendak Allah. Kehendak yang menuntut agar sepenuhnya melakukan apa yang Allah kehendaki.

Penyangkalan diri ditunjukkan oleh Paulus. Dia memberikan pernyataan bahwa apa yang dahulu dianggap sebagai keuntungan sekarang dianggap rugi karena Kristus. Dia melepaskan semuanya itu dan menganggapnya sebagai sampah (Flp. 3: 7-8). Paulus memiliki pendidikan yang sangat baik dalam agama Yahudi sehingga dia memiliki kesempatan yang besar untuk memiliki kedudukan dalam jabatan agama Yahudi. Perjumpaannya dengan Yesus ketika perjalanan ke Damsyik mengubah seluruh sudat pandangnya. Dia melupakan apa yang telah diperolehnya selama ini dan terus menuju kepada tujuan akhir yaitu Kristus.

Paulus juga membuat pernyataan dalam Galatia 2: 20. Di ayat ini Paulus menunjukkan bahwa hidupnya bukan milik pribadi lagi, melainkan Kristus yang berkuasa atasnya.Keunggulan pribadi telah ditundukkan sepenuhnya kepada Kristus.Aturan Kristus yang berlaku atas kehidupan pribadi. Bagi Hendriksen, penyangkalan diri berarti menunjukkan diri sepenuhnya kepada disiplin Kristus.

${ }^{16}$ Hendriksen, Galatia, Ephesians, Philippians, Colossians, and Philemon, 107.

17 Chrisope, Mengakui Yesus Sebagai Tuhan, 130. 
Segala yang merupakan keuntungan diri telah berada sepenuhnya di bawah Kristus. ${ }^{18}$ Paulus menjadi manusia baru di dalam Kristus.Dia masih tetap pribadi yang bertubuh yang masih bisa untuk berdosa.Masih ada kelemahan yang tersimpan di dalam tubuh sekalipun telah menjadi manusia baru di dalam Kristus. ${ }^{19}$ Penaklukkan diri Paulus secara utuh bukan karena tuntutan hukum secara manusia melainkan karena iman kepada Yesus Kristus.

Penyangkalan diri bisa juga menjadi suatu penderitaan awal bagi seseorang yang mengikut Yesus.Melepaskan semua kebanggaan diri bukanlah hal yang mudah. Seseorang akan kehilangan apa yang dahulu menjadi bagian penting dari hidupnya. Dia akan memasuki fase belajar dengan hal baru yang bertentangan dengan kebiasaan selama ini. Fase itu menjadi awal untuk memasuki persekutuan yang intim dengan Yesus.

Memasuki persekutuan dengan Yesus, berarti siap menerima semua risiko yang sudah tersedia.Yesus telah memberikan contoh dengan meninggalkan surga dan masuk ke dunia dalam keadaan yang serba kekurangan. Dia adalah pemilik alam semesta, namun harus meninggalkan semuanya itu untuk memenuhi tugas yaitu menebus umat-Nya.Pengosongan diri Yesus akan menjadi bagian dalam pengikut-Nya.

\section{Memikul Salib}

Bagian kedua dari pemuridan yang diberikan oleh Yesus adalah memikul salib.Bagi Chrisope, memikul salib bukan hanya merujuk kepada kerepotan kecil dalam kehidupan sehari-hari, melainkan melibatkan kematian. Istilah memikul salib bisa saja dimengerti secara literal yaitu kematian murid sebagai martir,

${ }^{18}$ Hendriksen, Galatia, Ephesians, Philippians, Colossians, and Philemon, 107.

19 Thomas R. Schreiner, Exegetical Commentary on the New Testament: Galatians (Grand Rapids: Zondervan, 2010), 173. 
namun bisa juga sebagai kiasan. ${ }^{20}$ Pendapat Chrisope memberikan dua kemungkinan pemaknaan terhadap frasa memikul salib.Jika pengetian ditujukan kepada maksud perkataan Yesus pada saat itu. Dia memberikan pernyataan bahwa para murid akan mengalami kematian seperti yang akan Dia alami. Makna kiasan tedapat dalam Injil Lukas. Di Injil Lukas terdapat frasa setiap hari. Menurut Chrisope:

Catatan Lukas (Luk. 9: 23) memasukkan istilah "setiap hari" ("memikul salibnya setiap hari") dan ini pasti mengandung makna kiasan karena diperlukan diperlukan tindakan yang berulang (sedangkan secara literal seseorang hanya bisa mati satu kali; meskipun tentu saja terus-menerus bersiap mati sebagai martir bisa dimaksudkan di sini). ${ }^{21}$

Frasa setiap hari menunjukkan ativitas yang terus berlanjut.Aktivitas yang terus berlanjut menunjukkan bahwa seseorang memikul salib bukan hanya mengenai kematian karena Kristus, namun ada hal lain yang menjadi bagian dari memikul salib. Menurut Hendriksen, memikul salib menuntut tanggung jawab dari manusia. Seseorang yang memikul salibnya harus menundukkan dirinya di bawah hukum Kristus. ${ }^{22}$ John Stott memberikan empat sumber penderitaan. Pertama, penderitaan merupakan serangan satan yang dektruktif terhadap Sang Pencipta. Kedua, penderitaan sering kali disebabkan oleh dosa. Ketiga, penderitaan disebabkan oleh sensivitas manusiawi kita terhadap rasa sakit. Keempat, penderitaan disebabkan oleh jenis lingkungan di mana Allah menempatkan kita. Keempat poin tersebut merupakan sumber penderitaan yang bisa saja dialami baik oleh orang percaya maupun oleh orang yang tidak percaya.Sumber itu masih umum terjadi.

20 Chrisope, Mengakui Yesus Sebagai Tuhan, 129.

21 Chrisope, 130.

22 William Hendriksen, Luke (Grand Rapids: Baker Academic, 2007), 498. 
Penderitaan orang percaya merupakan bagian dari proses pemurnian di dalam Kristus. Orang percaya diharapkan tidak berusaha menolak penderitaan yang benar-benar karena Kristus.Penderitaan itu harus dihadapi dengan sabar.Stott menyatakan, "Sekalipun penderiaan harus diakui jahat dan karenanya ditolak, tetap saja ada saat di mana penderitaan harus diterima secara realistis. Pada saat itulah teladan Yesus, yang diberikan kepada kita di dalam Perjanjian Baru untuk kita ikuti, menjadi inspirasi." 23 Penderitaan Yesus selama di dunia akan menjadi kekuatan tersendiri bagi orang percaya untuk bertahan dalam menghadapi penderitaan karena Kristus. Ketundukan Yesus kepada kehendak Bapa memberikan teladan kepada orang Orang Percaya dalam menghadapi penderitaan. Orang percaya bersedia menderita bagi kehendak Allah. ${ }^{24}$

\section{Mengikut Yesus}

Ketiga poin ini dituliskan dalam injil Sinoptik. Syarat untuk mengikut Yesus menjadi penekanan yang memiliki tempat yang penting. Syarat itu menjadi bagian yang tak terpisahkan dari proses yang akan diterima oleh orang yang masuk dalam persekutuan dengan Yesus. Tahapan demi tahapan akan dilalui. Seorang murid tidak dapat menghindari proses ini. Proses yang akan membawa seorang murid tahan uji di dalam Yesus. Hendriksen menyatakan, "If anyone wishes to be (counted as) an adherent of mine, he must once and for all say farewell tp self, decisively accept pain, shame, and persecution for my sake and in my cause, and must then follow and keep on following me as my disciple."25 Tindakan mengikut Yesus adalah bagian terakhir dari pemuridan. Setelah melalui proses penyangkalan diri dan memikul salib, seseorang akan memasuki tahap

23 John R. W. Stott, Salib Kristus (Surabaya: Momentum, 2015), 402.

${ }^{24}$ Chrisope, Mengakui Yesus Sebagai Tuhan, 132.

25 William Hendriksen, Matthew (Grand Rapids: Baker Academic, 2007), 656. 
mengikuti. Pengambilan keputusan akan dilakukan. Proses penyangkalan diri dan memikul salib akan tetap ada selama mengikut Yesus, namun tahap awalnya telah dilalui. Pemuridan akan tetap berjalan selama manusia ada di dunia. Seorang yang telah mengikut Yesus pasti akan tetap menghadapi persoalan yang mengharuskan dia melalui semua proses pemuridan yang telah dilalui.

Keputusan untuk mengikut Yesus menuntut sikap yang radikal. Dalam Matius 10: 37 dituliskan bahwa seseorang yang lebih mengasihi keluarganya dibangdingkan dengan Yesus, maka dia tidak layak untuk mengikut Yesus.Tuntutan untuk membuat pemisahan yang jelas menjadi bagian yang penting dalam mengikut Yesus. Di ayat selanjutnya, Yesus memberikan peringatan agar orang yang mengikuti-Nya harus bersedia memikul salibnya. Memikul salibnya dihubungkan langsung dengan pemilihan antara mempertahankan nyawa atau kehilangan nyawa. Dari pernyataan Yesus sangat jelas bahwa mengikut Yesus akan melibatkan seluruh kehidupan. Tuntutan bukan hanya keluarga semata, melainkan nyawapun menjadi taruhannya.

Yesus telah memperlihatkan dengan jelas mengenai hal-hal yang akan menimpa orang-orang yang datang kepada-Nya.Keteladanan yang diberikan-Nya, telah menjadi kekuatan tersendiri dalam kehidupan orang percaya, sehingga dapat bertahan dalam menghadapi penderitaan di dunia. Orang percaya dalam setiap generasi telah mengalami penderitaan, inspirasi memikul penderitaan yang tidak selayaknya diterima dengan sikap sabar dan tanpa menyerang balik merupakan sikap yang telah ditunjukkan oleh Yesus sebelumnya. ${ }^{26}$ Penekanan mengenai keserupaan antara penderitaan yang dialami oleh Yesus dengan orang-orang yang

26 Stott, Salib Kristus, 403. 
akan mengikuti-Nya dituliskan dalam surat-surat lainnya. Penderitaan akan dialami oleh setiap orang yang akan hidup dalam nama Yesus. Dunia akan menolak mereka. Hal itu telah disampaikan dan ditunjukkan oleh Yesus ketika berada di dunia. Seorang pengikut Yesus dituntut kesiapan sebab akan berhadapan dengan kenyataan bahwa dunia menolak mereka.

Yesus memberitahukan kepada murid-Nya bahwa mereka akan dibenci oleh dunia. Kebencian itu terjadi sebab dunia sudah terlebih dahulu membenci Yesus. Kebencian dunia terhadap Yesus akan dirasakan juga oleh murid-muridNya. ${ }^{27}$ Kebencian ini terjadi karena status mereka telah berubah. Yesus menyatakan bahwa mereka telah diambil oleh Yesus dari dunia sehingga bukan lagi orang yang serupa dengan dunia melainkan telah menjadi bagian dalam persekutuan dengan Yesus (Yoh. 15: 18-19). Andreas J. Kostenberger menyatakan, "Murid-murid perlu diberitahu tentang kebencian dunia, karena selama pelayanan Yesus di bumi, Yesuslah, bukan murid-murid, yang menanggung beban utama dari penyiksaan yang ditimpakan dunia ini (termasuk para pemimpin bangsa Yahudi), namun segera setelah Yesus pergi, kebencian dunia tidak terhindarkan akan diarahkan kepada mereka., 28

Dunia membenci Yesus dan pengikut-Nya sebab mereka bukan miliknya. Dunia mencintai apa yang dimilikinya sama seperti Yesus mengasihi milik-Nya. Kecintaan dunia terhadap miliknya harus diperhatikan lagi sebab hal ini bukan menyangkut sistem yang ada di dunia.Kecintaan itu bisa menyangkut kuasa

${ }^{27} \mathrm{Hal}$ serupa juga dituliskan oleh Leon Morris. Bagi Morris, dunia telah membenci Yesus, maka dunia juga pasti akan membenci pengikut-Nya. Jika kebencian itu muncul, para murid tidak akan heran lagi sebab mereka telah melihat dan merasakannya. (Lih: Leon Morris, The Gospel According to John (Grand Rapids: Eerdmans, 1995), 602.)

${ }^{28}$ Andreas J. Kostenberg, Encountering John: Injil dalam Perspektif Sejarah, Sastra, dan Teologis (Malang: SAAT, 2015), 185. 
dunia.Dia mencinta orang yang dekat kepadanya.Dunia memiliki kesamaan nilai yang dapat saling bersatu dalam membentuk pertentangan terhadap nilai yang dibawa oleh Yesus.Nilai di dunia dapat saling memahami, namun nilai yang dari atas yang dibawa oleh Yesus tidak dapat dipahami oleh dunia. ${ }^{29}$

Kebencian dunia bukan secara sistem melainkan nilai.Nilai yang ada di dunia berbeda dengan nilai dari atas yang diberikan Yesus kepada pengikut-Nya. Perbedaan itu menyebabkan pertentangan sebab sangat asing bagi dunia.Sekalipun ada nilai yang berbeda dalam dunia namun dapat saling memahami, berbeda dengan nilai yang dibawa oleh Yesus. Nilai itu sulit diterima oleh dunia. Kebencian yang diberikan dunia kepada pengikut Yesus hampir sama dengan kebencian bangsa lain kepada orang Yahudi. Kebencian terhadap sikap yang tidak mau kompromi terhadap nilai-nilai yang bertentangan dengan kepercayaan mereka. Pengikut Yesus juga menunjukkan sikap tidak mau kompromi terhadap nilai yang bertentangan dengan ajaran Yesus. ${ }^{30}$

Keterpisahan dengan dunia memberikan penolakan terhadap orang-orang yang ada di dalam Yesus.Orang yang ada di dalam Yesus berarti telah meninggalkan kehidupan lama dan menerima kehidupan yang baru.Kehidupan yang menjadi ciri khas dari pengikut Yesus. Perubahan inilah yang menyebabkan dunia membenci mereka. Pekerjaan dunia yang selama ini menjadi bagian dari kehidupan harus disangkal sebab bertentangan dengan persekutuan dalam Yesus, dan dunia tidak dapat menerima perubahan itu.Yesus menyatakan bahwa orang datang kepada-Nya telah diambil dari dunia. Diambil bukan berarti tidak hidup di dalam dunia lagi, melainkan telah berbeda dengan cara hidup dunia. Bagi Morris, 2005), 1019

30 Keener, 1019. 
frasa "Sekiranya kamu dari dunia" menyiratkan bahwa mereka tidak dari dunia lagi. ${ }^{31}$ Asal mereka telah berubah saat Yesus memilih mereka.Mereka bukan lagi pencinta dunia sebab telah ada di dalam Kristus.

Morris menegaskan bahwa bentuk present dari kata kerja terakhir menunjukkan suatu proses yang berkelanjutan. Yohanes memberikan penekanan dengan mengulang satu kata. Kata "dunia" sepertinya sengaja dibuat lama dalam pikiran dengan mengulanginya sebanyak lima kali dalam satu ayat. ${ }^{32}$ Orang percaya akan mengalami kebencian dari dunia secara berkelanjutan. Dunia tidak akan berhenti pada generasi pertama melainkan akan terus melakukan itu. Dunia akan tetap seperti apa adanya dan orang percaya akan tetap seperti itu. ${ }^{33}$ Keduanya tidak akan pernah menyatu. Menurut Houwelingen: "Anugerah ini (karena dipakai sejajar dengan kleos, charis mempunyai arti aslinya) adalah kemampuan untuk "menanggung penderitaan yang tidak harus ia tanggung" (artinya tahan diperlakukan dengan tidak adil), dan untuk benar-benar menderita."34 Ketika Yesus menyampaikan doa untuk murid-murid-Nya, Dia meminta kepada Bapa agar melindungi mereka. Permohonan itu disampaikan sebab Yesus akan meninggalkan para murid dan orang-orang percaya selanjutnya. Mereka akan tetap di dalam dunia, namun berbeda dengan dunia yang mereka tempati. Perbedaan itu akan menjadikan mereka musuh bagi dunia. Akan banyak tantangan yang dihadapi oleh pengikut-Nya. Yesus tidak meminta Bapa untuk memisahkan total antara pengikut-Nya dengan dunia, melainkan melindungi mereka sebab mereka masih berada di dalam dunia. Perlindungan yang diberikan oleh Bapa

31 Morris, The Gospel According to John,439 .

32 Morris, 439.

33 Morris, 440. 162.

${ }^{34}$ P. H. R. van Houwelingen, Surat 1 Petrus: Surat Edaran dari Babel (Surabaya: Momentum, 2018), 
merupakan wujud dari jaminan yang diberikan oleh Yesus bahwa tidak seorang pun akan hilang dari orang-orang yang telah diberikan Bapa kepada-Nya.

\section{KESIMPULAN}

Orang percaya telah diberikan suatu peringatan akan penderitaan yang akan menimpa. Yesus tidak menjamin kehidupan yang nyaman dan enak kepada setiap orang yang datang kepada-Nya. Matius 10: 34 menuliskan bahwa Yesus datang bukan untuk membawa dalam melainkan pedang.Dia membawa pemisahan antara orang yang mengasihi Dia dan orang yang mengasihi dunia. Pemisahan itu akan mengakibatkan banyak tantangan pada orang mengalami pemisahan tersebut. Orang percaya menemui penderitaan lain yang merupakan kerja sama beberapa sumber. Sumber-sumber tersebut bertolak belakang dengan keadaan baru dari orang percaya, sehingga mereka memberikan perlawanan. Nilai-nilai yang ada pada orang percaya sangat tidak mungkin untuk dipadukan. Perbedaan ini membawa pada penderitaan yang hanya dialami orang percaya saja. 1Korintus 10 : 13 memberikan penghiburan orang percaya dalam pencobaan. Penderitaan itu bukan berasal dari kesalahan pribadi melainkan karena ketidakadilan. Kesabaran menghadapi penderitaan karena ketidakadilan merupakan anugerah Allah. Keserupaan dengan Yesus dalam penderitaan bisa juga ditemui dalam kehidupan sehari-hari. Seseorang yang mengikut Yesus bisa mendapatkan penolakan dari keluarga dan lingkungannya. Orang percaya bisa saja dicemooh karena kepercayaannya yang dianggap tidak masuk akal. Anak-anak Kristen dihina sebab memiliki Tuhan yang bisa menderita dan mati. Keadaan itu akan menjadi bagian dalam kehidupan orang yang percaya kepada Yesus. Ketika hal itu terjadi, maka Yesuslah yang menjadi contoh dan kekuatan bagi orang percaya. 


\section{DAFTAR PUSTAKA}

Apps, Other. "Pengertian Studi Kepustakaan." Diakses 11 Oktober 2020. https://www.transiskom.com/2016/03/pengertian-studi-kepustakaan.html.

Bock, Darrell L. Jesus According to Scripture: Restoring the Portrait from the Gospels. Grand Rapids: Baker Academic, 2002.

Chrisope, Terry A. Mengakui Yesus Sebagai Tuhan. Surabaya: Momentum, 2018.

Hendriksen, William. Galatia, Ephesians, Philippians, Colossians, and Philemon. Grand Rapids: Baker Academic, 2007.

—. Luke. Grand Rapids: Baker Academic, 2007.

—. Matthew. Grand Rapids: Baker Academic, 2007.

Houwelingen, P. H. R. van. Surat 1 Petrus: Surat Edaran dari Babel. Surabaya: Momentum, 2018.

Keener, Craig S. The Gospel of John: A Commentary. Vol. 2. Peabody: Hendrickson Publisher, 2005.

Kostenberg, Andreas J. Encountering John: Injil dalam Perspektif Sejarah, Sastra, dan Teologis. Malang: SAAT, 2015.

Martin, R. P. "Kenosis.” Dalam Ensiklopedi Alkitab Masa Kini, 1:545. 1. Jakarta: YKBK, 2011.

Morris, Leon. Injil Matius. Surabaya: Momentum, 2016.

—. The Gospel According to John. Grand Rapids: Eerdmans, 1995.

Schreiner, Thomas R. Exegetical Commentary on the New Testament: Galatians. Grand Rapids: Zondervan, 2010.

Stott, John R. W. Salib Kristus. Surabaya: Momentum, 2015.

Supriadi, Made Nopen, dan Iman Kristina Halawa. "Makna Penderitaan Kristus Dalam 1Petrus 2: 18-21." Manna Rafflesia 5, no. 1 (Oktober 2018): 6991. https://doi.org/10.38091/man_raf.v5i1.99.

Zaluchu, Sonny. "Penderitaan Kristus Sebagai Wujud Solidaritas Allah Kepada Manusia." Dunamis: Jurnal Teologi dan Pendidikan Kristiani, 2017, 6174. 